\title{
Veratridine increases the survival of retinal ganglion cells in vitro
}

S.P.F. Pereira ${ }^{1,2}$ and E.G. Araujo ${ }^{1}$

\author{
'Departamento de Neurobiologia, Instituto de Biologia, \\ Universidade Federal Fluminense, Niterói, RJ, Brasil \\ ${ }^{2}$ Departamento de Farmacologia Básica e Clínica, Instituto de Ciências Biomédicas, \\ Universidade Federal do Rio de Janeiro, Rio de Janeiro, RJ, Brasil
}

\author{
Correspondence \\ S.P.F. Pereira \\ Departamento de Neurobiologia \\ Instituto de Biologia, UFF \\ Caixa Postal 100180 \\ 24001-970 Niterói, RJ \\ Brasil \\ Fax: 55 (021) 719-5934 \\ E-mail: adrianno@openlink.com.br \\ Research supported by CEG-UFF, \\ FAPERJ and FINEP. S.P.F. Pereira \\ is the recipient of a CNPq \\ fellowship. The present address \\ of S.P.F. Pereira is Instituto de Biofísica \\ Carlos Chagas Filho, CCS, UFRJ, \\ 21949-900 Rio de Janeiro, RJ, \\ Brasil.
}

Received June 9, 1997

Accepted September 1, 1997

$\ldots \ldots \ldots \ldots \ldots \ldots$

\begin{abstract}
Neuronal cell death is an important phenomenon involving many biochemical pathways. This degenerative event has been studied to understand how the cells activate the mechanisms that lead to selfdestruction. Target cells and afferent cells play a relevant role in the regulation of natural cell death. We studied the effect of veratridine $(1.5,3.0,4.5$ and $6.0 \mu \mathrm{M})$ on the survival of neonatal rat retinal ganglion cells in vitro. Veratridine $(3.0 \mu \mathrm{M})$, a well-known depolarizing agent that opens the $\mathrm{Na}^{+}$channel, promoted a two-fold increase in the survival of retinal ganglion cells kept in culture for $48 \mathrm{~h}$. This effect was dose-dependent and was blocked by $1.0 \mu \mathrm{M}$ tetrodotoxin (a classical voltage-dependent $\mathrm{Na}^{+}$channel blocker) and $30.0 \mu \mathrm{M}$ flunarizine (a $\mathrm{Na}^{+}$and $\mathrm{Ca}^{2+}$ channel blocker). These results indicate that electrical activity is also important for the maintenance of retinal ganglion cell survival in vitro.
\end{abstract}

Key words

- Veratridine

- Retinal ganglion cells

- Natural cell death

- Development

- Retina
The development of the nervous system is generally characterized by different and important events that control the normal functioning of the system. Natural cell death occurs concomitantly with the period of synaptogenesis modulating the neuronal cytoarchitecture (1). This degenerative phenomenon plays an important role in the stabilization of the neural circuitry and can be observed during the evolution of species (2).

The regulation of neuronal death is mediated by a wide variety of events responsible for neuronal survival (3). Neurotrophic factors such as nerve growth factor or brainderived neurotrophic factor among others are essential for the maintenance of neuronal survival during certain stages of development (4). Previous studies have shown that developing retinal cells release trophic fac- tors that maintain the survival of retinal ganglion cells (5). It has also been shown that neurotrophic factors are able to rescue neurons in the adult stage (6).

Electrical activity generated by afferent cells is also very important for the control of cell death. The blockade of this activity induces neuronal degeneration either during early stages of development or in the adult phase (7). Neurons deprived of trophic molecules can survive in vitro when kept chronically depolarized with high $\mathrm{K}^{+}$concentration or veratridine $(8,9)$. Membrane depolarization induced by high potassium concentrations elicits an influx of calcium through voltage-dependent $\mathrm{L}$ type calcium channels (10). The precise mechanism by which veratridine induces neuronal survival is not well known. Thus, neurotrophins produced 
Figure 1 - Dose-dependent effect of veratridine on the survival of retinal ganglion cells. The effect was tested after 48-h in vitro treatment with different concentrations of veratridine. Data are reported as the mean \pm SEM of three different experiments, each performed with at least three different dishes. ${ }^{*} \mathrm{P}<$ 0.001 and ${ }^{*} P<0.05$ compared to the 48-h control (ANOVA followed by the Newman-Keuls test).

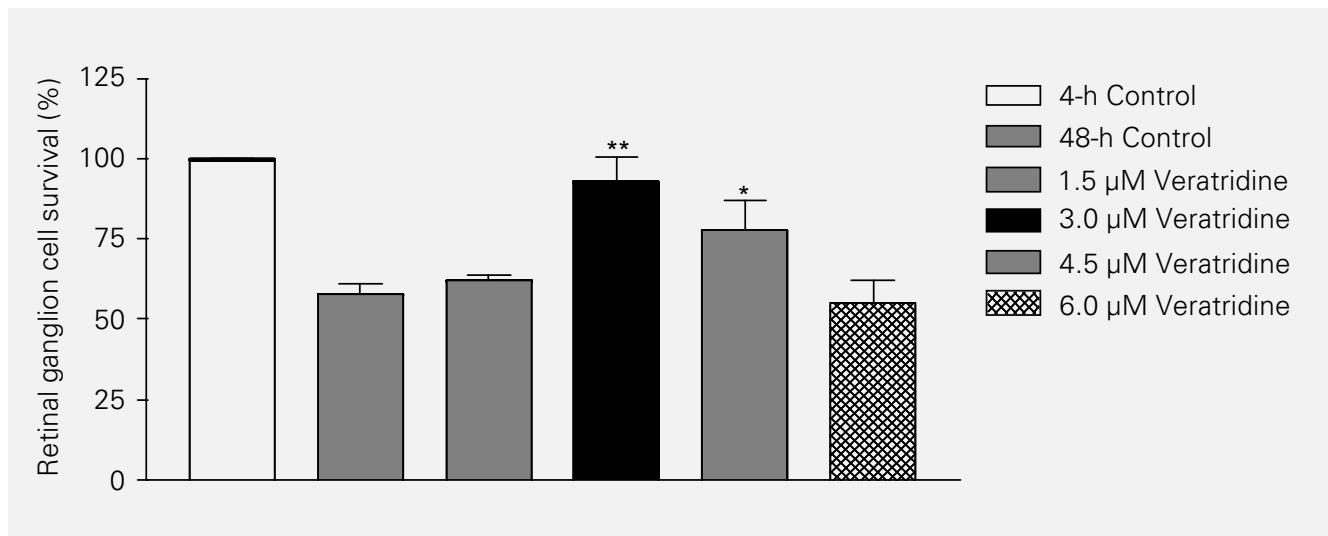

by target and afferent cells and the generation of electrical activity by afferent cells are essential to the survival of neuronal cells (11).

The aim of the present study was to determine the effect of veratridine on the survival of retinal ganglion cells after $48 \mathrm{~h}$ in vitro. Neonatal Lister Hooded rats were anesthetized by hypothermia within the first $24 \mathrm{~h}$ after birth and 1-1.5 $\mu \mathrm{l}$ of a $30 \%$ horseradish peroxidase solution in $2 \%$ dimethylsulfoxide was injected into each superior colliculus. After regaining their normal temperature, the animals were returned to their mothers for a period of 16 to $18 \mathrm{~h}$. Rats were then killed by decapitation and their retinas were dissected in a calcium- and magnesium-free salt solution and treated with $0.1 \%$ trypsin (Worthington, Freehold, NJ, USA) for 16 $\min$ at $37^{\circ} \mathrm{C}$. The cells were triturated with a polished Pasteur pipette, maintained in medium 199 (Gibco, Gaithersburg, MD, USA) supplemented with 5\% FCS, $2 \mathrm{mM}$ glutamine (Sigma Chemical Co., St. Louis, MO), $100 \mu \mathrm{g} / \mathrm{ml}$ streptomycin and $100 \mathrm{U} / \mathrm{ml}$ penicillin (Sigma) and plated onto coverslips previously treated with $50 \mu \mathrm{g} / \mathrm{ml}$ poly-Lornithine (Sigma) overnight. Cultures were maintained in a humidified atmosphere of $5 \% \mathrm{CO}_{2}$ and $95 \%$ air at $37^{\circ} \mathrm{C}$. Cells were incubated for 2-4 $\mathrm{h}$ to allow attachment to the coverslip. Control cultures were then fixed as described below while other cultures received $1 \mathrm{ml}$ of medium 199 alone or
$1 \mathrm{ml}$ of medium 199 containing the drugs to be tested. After $48 \mathrm{~h}$ the cultures were fixed in Karnovski's aldehydes, $2 \%$ glutaraldehyde and $1 \%$ paraformaldehyde in phosphate buffer, $\mathrm{pH} 7.2-7.4$, for 5 to $10 \mathrm{~min}$. The presence of peroxidase in the retinal ganglion cells was detected using the protocol described by Mesulan (12). Tetramethylbenzidine (Sigma) was used as chromogen. After reaction the coverslips were washed in $0.2 \mathrm{M}$ acetate buffer, dehydrated by air drying, immersed briefly in xylene and mounted in Entellan (Merck, Darmstadt, Germany). The number of retinal ganglion cells on each coverslip was evaluated by counting $1 / 20$ of the total with the use of a microscope grid. A Nikon microscope at a magnification of $400 \mathrm{X}$ under a bright field was used. The results are reported as percentage of control.

We observed a decrease in the number of retinal ganglion cells in control cultures after $48 \mathrm{~h}$, whereas cultures treated with veratridine showed a significant increase in the survival of retinal ganglion cells. This effect was dose-dependent. Veratridine at a concentration of $1.5 \mu \mathrm{M}$ did not show any effect on retinal ganglion cell survival. However, 3 $\mu \mathrm{M}$ veratridine stimulated an increase in survival. Very often, all initially plated retinal ganglion cells were still viable after $48 \mathrm{~h}$ and this effect was still observed at the concentration of $4.5 \mu \mathrm{M}$. When we used $6 \mu \mathrm{M}$ veratridine we observed a toxic effect (Figure 1). 


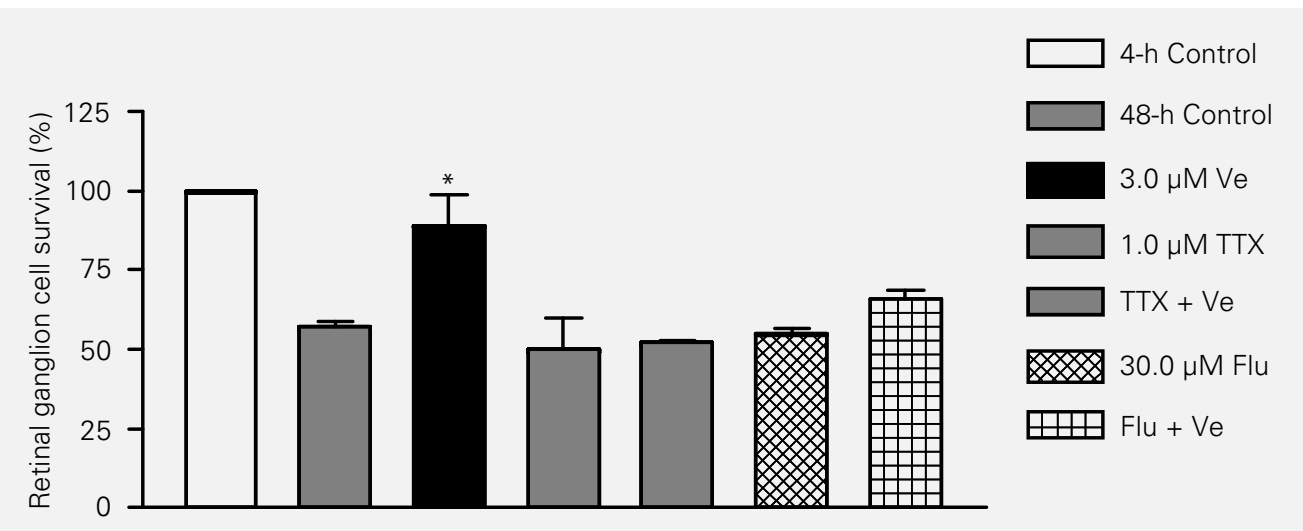

We also studied the relationship between the effect of veratridine and the activation of voltage-dependent sodium channels. The blockade of these channels with $1 \mu \mathrm{M}$ tetrodotoxin inhibited the increase in retinal ganglion cell survival induced by veratridine. The same result was obtained when $30 \mu \mathrm{M}$ flunarizine was used. This drug blocks either sodium or calcium channels (Figure 2).

Veratridine is a drug that has been used as an efficient tool for electrophysiology studies. This drug inhibits the complete inactivation of sodium channels, maintaining the channel open with a small but steady sodium current. It acts between the interface of the lipid bilayer and the protein subunit of the sodium channel. When the veratridine molecule is in place, it generates a change in the three-dimensional conformation of the sodium channels (13).

The present investigation is one of the first to use veratridine for the study of neuronal survival. Our data show that sodium channel activation is able to enhance the survival of retinal ganglion cells after $48 \mathrm{~h}$ in vitro. The use of veratridine generated a dose-dependent curve and the highest response was obtained at 3.0 $\mu \mathrm{M}$ extracellular concentration. Treatment with tetrodotoxin, a classic blocker of voltage-sensitive sodium channels, abolished the effect of veratridine, suggesting that these channels play a role in the enhancement of cell survival. Flunarizine, an inhibitor of sodium and calcium channels, also blocked the effect of veratridine. These data suggest that veratridine induces an influx of sodium and calcium ions and triggers different pathways that may contribute to the inhibition of neuronal death.

Veratridine as a depolarizing agent is a new tool that can also be used in the study of neuronal development. In the absence of target cells, neurons die and several lines of evidence indicate that this phenomenon is related to the absence of neurotrophic molecules (3). In the present study we showed that veratridine can increase the survival of retinal ganglion cells even in the absence of exogenous neurotrophic factors. The afferent activity, regulating the calcium influx and the release of calcium from cytoplasmic stores, is important for the maintenance of neuronal survival $(8,11)$. Until now we do not exactly know how veratridine increases the survival of retinal ganglion cells. Further studies will be necessary to elucidate the mechanism involved in the effect of veratridine in order to contribute to the understanding of the complex phenomenon known as natural cell death.

\section{Acknowledgments}

We acknowledge the technical assistance of Alexandre José Fernandes and Bernardino Matheus dos Santos.
Figure 2 - The effect of veratridine $(\mathrm{Ve})(3.0 \mu \mathrm{M})$ was inhibited by $30.0 \mu \mathrm{M}$ flunarizine (Flu) and $1.0 \mu \mathrm{M}$ tetrodotoxin (TTX). Data are reported as mean \pm SEM of three different experiments, each performed with at least three different dishes. ${ }^{*} P<0.001$ compared to the 48-h control (ANOVA followed by the Newman-Keuls test). 


\section{References}

1. Oppenheim RW (1991). Cell death during development of the nervous system. Annual Review of Neuroscience, 14: 453501.

2. Cepko CL (1993). Retinal cell fate determination. Progress in Retinal Research, 12: 1-12.

3. Snider WD (1994). Functions of the neurotrophins during nervous system development: what the knockouts are teaching us. Cell, 77: 627-638.

4. Barde Y-A (1989). Trophic factors and neuronal survival. Neuron, 2: 1525-1534.

5. Araujo EG \& Linden R (1993). Trophic factors produced by retinal cells increase the survival of retinal ganglion cells in vitro. European Journal of Neuroscience, 5: 1181-1188.
6. Thoenen H (1995). Neurotrophin and neuronal plasticity. Science, 270: 593-597.

7. Okada N \& Oppenheim RW (1984). Cell death of motoneurons in the chick embryo spinal cord. IX. The loss of motoneurones following removal of afferent inputs. Journal of Neuroscience, 4: 16351652.

8. Franklin JL \& Johnson Jr EM (1992). Suppression of programmed neuronal death by sustained elevation of cytoplasmic calcium. Trends in Neurosciences, 15: 501508.

9. Tanaka S \& Koike T (1995). Up-regulation of L-type $\mathrm{Ca}^{2+}$ channel associated with the development of elevated $\mathrm{K}^{+}$mediated survival of superior cervical ganglion cells in vitro. Developmental Biology, 167: 1-13
10. Collins F \& Lile JD (1989). The role of dihydropyridine-sensitive voltage-gated calcium channels in potassium mediatedneuronal survival. Brain Research, 502: 99-108.

11. Linden $R$ (1994). The survival of developing neurons: A review of afferent control. Neuroscience, 58: 671-682.

12. Mesulan MM (1982). Tracing Neural Connections with Horseradish Peroxidase. John Wiley \& Sons, New York.

13. Sutro JB (1986). Kinetics of veratridine action on $\mathrm{Na}^{+}$channels of skeletal muscle. Journal of General Physiology, 87: 1-24. 